\title{
The Role of Political Connections and Family Ownership in Increasing Firm Value
}

\author{
Momon $^{1}$, Lela Nurlaela Wati*,2, Sutar $^{2}$ \\ ${ }^{1}$ Universitas Padjadjaran, Bandung, Indonesia \\ ${ }^{2}$ Sekolah Tinggi Ilmu Ekonomi Muhammadiyah Jakarta, Indonesia
}

ARTICLE INFO

\section{Article history:}

Received 02 October 2020

Revised 19 November 2020 \& 17

February 2021

Accepted 25 February 2021

Published 15 March 2021

\section{Keywords:}

Firm value

Political connection

Family ownership

Controlling shareholder

\begin{abstract}
In the face of business competition, a company strategy is needed by seeking and exploiting opportunities in the business environment, one of which is through political connections. Ownership structure plays an essential role in the company to determine the firm performance. The high concentration of family ownership has the power to reduce agency conflicts between management and stakeholders in a company. Concentrated ownership can serve as corporate governance mechanism for better and effective monitoring of management. This study was conducted to determine empirical evidence of the effect of political connections and family ownership structure on firm value. The sample in this study was 390 data of the manufacturing company. The data analysis used is moderating regression analysis. The results of this study are a positive influence of political connections and family ownership structure on firm value. The results showed that the more the company had a strong political connection and was controlled by the family, the more the firm value would increase. The interaction of political connections can strengthen the influence of family ownership on firm value. It proves that the family ownership structure plays a role in determining political connections in Indonesia, especially in manufacturing companies. The existence of empirical evidence that shows that the firm value controlled by a politically connected family is higher than companies that are not connected politically, which implies investors to invest in companies that are politically connected and companies controlled by families with majority ownership because it is proven to increase firm value.
\end{abstract}

\section{Introduction}

The main objective of the company is to obtain maximum profit, prosper the company owner or shareholders, and maximize firm value. To achieve company goals, a corporate strategy is needed by seeking and exploiting opportunities in the business environment, one of which is through political connections. The political connection is a condition of the relationship between business (company) and politics. Faccio (2006) explains that a company is said to be politically connected if one of the company's large shareholders or top management of the company is a member of parliament, a minister or head of state, or who has close relations (relatives) of them.

Political connections research in Indonesia was initiated by Fisman (2001), who examined go public companies on the Jakarta Stock Exchange (currently the IDX) and had connections with President Soeharto. Fisman produced that awful news about President Soeharto's health hit the Indonesian stock market, and companies close to Suharto suffered negative returns. The return on shares of companies that were politically connected to Suharto was lower than those of companies that were not politically connected. Leuz and Gee (2005) reinforce the findings of Fisman (2001), in which companies that are closely connected to Suharto experienced a deteriorating performance during the financial crisis, then recovered under Habibie's leadership, but were underperformed again after Abdurahman Wahid

* Corresponding author.

E-Mail address: lela_nwm@yahoo.com

ORCID: 0000-0001-7046-612X 
served as President. It suggests that companies with political ties to Suharto had difficulty building close relationships with the new Government when their patron fell from power, impacting the company's long-term financial performance.

Political connections have a positive impact on companies operating in countries that have high levels of corruption in the bureaucracy, weak in copyright protection, intervention by strong authorities, and undemocratic governance (Faccio, 2006). In facing intense business competition, a company strategy is needed to compete by seeking and exploiting opportunities in the business environment, one of which is through political connections. Faccio (2006) explains that to achieve good financial performance, companies engage in political relations because politics is one of the main determinants of the state's institutional environment. This is supported by Wati et al. (2016a), which shows that conglomerate companies controlled by political connections experienced a significant increase in the value of post-election market capitalization in both 2009 and 2014. The increase in the share price of these companies stated that entrepreneurs and company leaders in developing countries such as Indonesia with high levels of corruption, believing that political connections provide the lubricant for achieving company goals, so they make significant efforts to foster political connections to increase company growth.

Research on the effect of political connections on firm value is also documented by Goldman et al., 2009; Wong, 2010; Ang et al., 2013; Do et al., 2015; Wati et al., 2016b; Wati, 2017; Maulana and Wati, 2019 which show that political connections have a positive effect on firm value. In addition to the various benefits obtained by politically connected companies as mentioned above, political connections have a negative impact on the company, namely high leverage followed by overinvestment, lower stock prices, and stock returns, decreased company performance, and low quality of corporate financial statements (Chaney et al., 2011; Wu et al., 2012; Wati et al., 2020).

Ownership structure plays an essential role in the company to determine the performance of a company. La Porta et al., 1999; Claessens et al., 2000; Lukviarman, 2004; Kim, 2006; and Siregar, 2006, Wati et al., 2019 prove that companies in Indonesia have ownership structures that are concentrated in families. This is different from the corporate ownership structure in Europe and America, where the ownership structure in American and British companies is more spread over various ownership, but in other developed countries and especially developing countries are generally still controlled by families (La Porta et al., 1999). The intense political connections and the controlling role of the family in companies in Indonesia reflect poor corporate governance.

Claessens et al., (2000) documented that the capital market capitalization in Indonesia is $16.6 \%$ controlled by one family, and half of the market capitalization in Indonesia is controlled by the ten largest families in Indonesia. This result is supported by Wati et al. (2019) who examined the influence of controlling shareholders on firm value, where the family is the most essential controlling shareholder, which is $55.58 \%$ at $10 \%, 62.56 \%$ at $20 \%, 66.40 \%$ at $20 \%$. Separation of $30 \%, 67.84 \%$ at the separation of $40 \%$, and $68.10 \%$ at the separation of $50 \%$. The higher the separation, the greater the percentage of family ownership, this shows that the family is the primary controller in conglomerate companies in Indonesia. The results of research by Wati et al. (2019) do not differ significantly from the findings of Claessens et al. (2000) who found that as many as $54 \%$ of public companies controlled by families at a separation level of $10 \%$ control rights limit and companies controlled by the largest family were found in Indonesia, namely $69 \%$. At a split of $20 \%$, the number of family companies is $53 \%$, and the largest number of family-controlled companies is in Indonesia at $72 \%$.

On the one hand, the controlling shareholder in the company can effectively determine the policies implemented by management. Concentrated ownership can serve as a corporate governance mechanism to monitor better and more effective management that will reduce agency conflicts and thus have a positive impact on company performance or value. Isik and Soykan (2013), Martínez \& Requejo (2017), and Wati et al. (2019) proved that family ownership has a positive effect on firm value. However, on the other hand, the involvement of controlling shareholders in management is thought to be able to control company resources for personal gain and at the expense of minority shareholders' interests. The involvement of controlling shareholders in management cannot improve company performance, and this phenomenon will undoubtedly harm the interests of minority shareholders (Wati et al., 2019). This is supported by the findings of Kim et al. (2017), which states that there is a negative influence between ownership structure on firm value. Konijn et al. (2011) and Lins et al. (2011) examined the impact of controlling shareholders on firm value, and they found that companies with blockholder ownership had a negative effect on firm value.

Based on the description above, the results of previous studies obtained are still inconsistent, where there is a gap between previous researchers who examined the effect of political connections and family control ownership on firm value. On the one hand, political connections and family ownership can have a positive effect on company value; on the other hand, political connections and family ownership have a negative impact on company value. The role of political connections and family controlling shareholders in a company is still a puzzle. Does the role of political connections and controlling shareholders affect the value of the company? This study aims to examine the effect of 
political connections and family ownership structures on firm value in manufacturing companies in Indonesia. This study is different from previous researchers because it uses a level of ownership control (cut off) of 10\% -50\% for the influence of political connections and family control on firm value. To measure firm value using Tobin's $Q$ and to test the robust model using the Market to Book Value variable.

\section{Theoretical Background and Literature Review}

The theories underlying this research are agency theory (Jensen and Meckling, 1976; Shleifer and Vishny, 1997) and political theory (North, 1990 and Olson, 1993).

\section{Agency Theory}

Several studies have shown that there are three potential agency problems related to ownership, namely: (1) Conflict between management and shareholders (Jensen and Meckling, 1976). This conflict occurs when ownership is spread over the hands of many shareholders so that no one party can control management. Thus, management can run the company according to their wishes, without any supervision from shareholders. (2) Conflicts between controlling and non-controlling shareholders (Shleifer and Vishny, 1997). This conflict occurs when there is one majority shareholder as the controlling shareholder and several minority shareholders as non-controlling shareholders. This causes the majority shareholders to have absolute constraints so that they can take actions that benefit them, but disadvantage minority shareholders. Third, conflicts between managers and creditors; agency problems can also occur between managers and creditors who provide loans or capital to companies. The debt contract signed by the manager is carried out with the aim of guaranteeing that the manager will carry out economic activities that lead to efforts to repay the loan according to the agreed time. This encourages creditors to ensure managers work according to procedures to improve their ability to repay loan funds.

Different ownership structures lead to various conflicts of interest. In a company that is spread over ownership, managers can act opportunistically and take company resources for personal gain (Type I agency problems). Whereas in a company with one was controlling shareholder, the largest shareholder acts to eliminate conflicts of interest between managers and shareholders. This creates agency problems between controlling shareholders and noncontrolling shareholders (Type II agency problems), as concluded by Shleifer and Vishny (1997). When companies with some of the largest shareholders, these shareholders will monitor each other or a coalition to watch each other or a team to eliminate personal interests (Shleifer and Vishney, 1997).

The condition of the ownership structure of a company will affect the form of agency problems between managers and outside shareholders, and among shareholders (Claessens et al., 2002). If ownership is concentrated in someone who has effective control over the company, as is the case in Asia, the agency problem will shift from a managershareholder conflict to a conflict between the controlling owner (often as company manager) and minority shareholders (Claessens et al., 2002).

\section{Firm Value}

Firm value is the sum of the present value of future cash flows generated by the company's current assets plus potential investment projects. The current share value not only reflects current earnings capacity but also reflects expectations of future operating and investment performance (Brealey and Myers, 2003 in Wati 2017). Firm value can be seen from the maximization of shareholder wealth. Firm value is related to stock prices, by looking at high stock prices, the firm value is also high. A high firm value will make the market believe not only in the company's current performance but also in the company's prospects.

In this study, firm value uses Tobin's Q developed by Lindenberg and Ross (1981). Companies with high Tobin's $\mathrm{Q}$ or Q>1.00 indicate that investment opportunities are better, have high growth potential, and indicate that management is well valued with assets under its management. The higher Tobin's $Q$ value, the higher the firm's value (Wati et al., 2019). 


\section{Political Connection}

North (1990) and Olson (1993) developed a theory of political connections, in which politicians or government figures build relationships with companies to achieve a government agenda that benefits the supporters of the politician or Government. Companies with political connections will receive benefits such as lucrative contracts or subsidies for their political contributions and votes. Profits that flow from these political connections make companies with political networks inefficient and build a culture of inefficiency because of their "protected" status (Wati, 2017).

The notion of political connection still does not have an agreed standard definition so that each researcher has a different meaning of political connection in his research. A politically connected firm as a company that, in specific ways, has political ties or seeks closeness to politicians or the Government (Purwoto, 2011). Company leaders who frequently develop personal relationships with public officials (for example, friendship, shared education with politicians and work experience, and campaign donations).

A company can be said to have a political relationship if at least one of the company's leaders, majority shareholders, or their relatives has been or is currently serving as a high ranking state official, member of parliament, or an official of the ruling party. With that, a political connection is about the close relationship between companies and the authorities. A company that has a relationship with the rules gets strategic benefits, such as knowing earlier about the regulations made by the Government (Faccio, 2006 and Wati, 2017).

A company that has a relationship with the authorities obtains strategic benefits, such as knowing earlier about the regulations made by the Government. For example, if the Government removes subsidies for gasoline and diesel, the company at least already knows the policy the Government wants to make. This is the advantage of companies with political ties. According to Goldman et al. (2009), companies even get benefits, especially in terms of reducing competition costs, reducing regulatory obligations, or making it easier to get contracts related to government projects. For example, in Indonesia, companies related to the regime have their privileges in terms of import permits compared to their competitors (Mobarak and Purbasari, 2005).

Besides having a positive impact, political connections also have a negative effect. Wati et al. (2020) state that political connections are like two sides of the sword that can have a positive and negative impact on a company. On the one hand, political connections can provide convenience for companies in various accesses, namely access to funding, procurement contracts with the Government, subsidies, taxes, ease of obtaining permits, and other amenities that have an impact on firm value. But on the other hand, to cover the costs incurred by the company, not a few connected companies manipulate their financial statements, which has a negative impact on the integrity of the company's financial statements. Chaney et al. (2011) show that the quality of the financial statements of companies with political connections is lower than the quality of financial statements of companies with political connections. This is supported by Wati et al. (2019), which shows that political connections have a negative impact on the quality of corporate financial reports. The political connections built by entrepreneurs can also result in high leverage, followed by overinvestment (Wu et al., 2012).

\section{Family Ownership Structure}

Family ownership is ownership of shares by individuals and companies that are not public. According to La Porta et al. (1999), family ownership is the ownership of individuals and ownership of closed companies (above 5\%) that are not public companies, state, or financial institutions.

La Porta et al. (1999) surveyed the ownership structure of going public companies in 27 rich countries. Using the $20 \%$ control definition (meaning that the company has controlling shareholders if there are one or more shareholders who have a share of $20 \%$ or more if none means the ownership is spread), they found that $30 \%$ is controlled by the family. When the definition of control is lowered to $10 \%$ or more, the ownership controlled by the family increases by $35 \%$, from the results of this study, it can be seen that in most large companies in developed countries, ownership is concentrated and the main controller is family.

Claessens et al. (1999) show that the main control of the corporate sector rests with a small number of families in most countries, including Indonesia. This can be demonstrated by the number of companies and the market value at the end of 1996 of the total assets controlled by the largest family groups in each of the six largest conglomerates in Indonesia.

Claessens et al. (2000) examined the ultimate control pattern, using 2,980 firms in nine East Asian countries (Hong Kong, Indonesia, Japan, South Korea, Malaysia, the Philippines, Singapore, Taiwan, and Thailand). They prove that more than two-thirds of companies are controlled by a single shareholder, and more than $50 \%$ of companies are controlled by the family. While the ownership structure in Japan is scattered, most companies in Indonesia and Thailand are controlled by families. The separation of ownership and control is most pronounced among family- 
controlled companies and small companies (Korea, Singapore, and Taiwan). About $60 \%$ of the top management of companies is controlled by the family as the controlling shareholder. The ten largest families in Indonesia, the Philippines, and Thailand control half of the company's assets in the study sample.

The results of the research of Wati et al. (2019) support the findings of Claessans et al. (2000), where the family is the most important controlling shareholder, namely $55.58 \%$ at $10 \%, 62.56 \%$ at $20 \%, 66 ., 40 \%$ at $30 \%$ boundary separation, $67.84 \%$ at $40 \%$ boundary separation, and $68.10 \%$ at $50 \%$ boundary separation. The higher the separation, the greater the percentage of family ownership, this shows that the family is the main controller in conglomerate companies in Indonesia.

The existence of weak property rights protection is one of the possibilities for high concentrated ownership in Asian countries, as shown by the low legal system, weak law enforcement, and high corruption. Likewise, it is this fragile system of rights protection in Asia that may explain why family-run business groups are the most dominant form of organization (Claessens et al., 2002).

\section{Hypothesis Development}

\section{The Effect of Political Connection on Firm Value}

This study predicts firm value through the information contained in political connections. Politically connected companies are companies that in specific ways, have political ties or seek closeness with politicians or the Government (Purwoto, 2011). The political connection can increase the firm value if it succeeds in removing unfair economic rent at the expense of competitors and consumers. However, if all or most of the value of the company is consumed by politicians and managers connected to these politicians, then shareholders will only get a fraction of the remaining value available (Faccio, 2006).

The intense political connections and the controlling role of the family in companies in Indonesia, with weak legal protection and high levels of corruption, make political connections very valuable to companies. Political connections have proven to be able to provide preferential treatment and convenience in various accesses; such as easy access to funding, government procurement contracts, public policies, subsidies and taxes, ease of trade licensing, access to company IPOs (Wati, 2017). However, in addition to the various benefits that a company gets that is politically connected, political connections also have a negative impact on the company. Fan et al. (2004), examined the CEOs and boards of directors of companies newly listed (IPO) on the Shanghai Stock Exchange from 1993-2000. A total of 625 IPO companies, with 5,000 directors. Nearly $28 \%$ of the CEOs in a sample of 625 firms were former or then government bureaucrats. The result of the research states that the accounting performance and stock returns of companies run by politically connected CEOs are relatively lower than those of companies with less politically connected CEOs. The appointment of a politically connected CEO cannot increase shareholder value but only serves the political goals of the politician. Xu and Zhou (2008) reveal that the disclosure of the Shanghai social security fund scandal that brought down Shanghai's top official Chen Liangyu is evidence that political connections have a negative impact on the company.

$\mathrm{Li}$ and Xia (2013) obtain empirical evidence that the growth of companies connected to politics has no significant impact on firm value. Political connections had an insignificant impact on the firm value before the financial crisis. Wati et al. (2020a) show that the quality of the financial statements of companies with political connections is worse than companies that are not politically connected. Politically connected companies often carry out earnings management by way of over-statements (Wati et al., 2020b).

Political connections to companies in developing countries with high levels of corruption, such as Indonesia, which occupies the 85th position out of 179 countries in 2019 (Corruption Perception Index, 2020), still firmly believes that political connections provide various facilities to achieve corporate goals, companies realizes that political connections are a strategy as well as a valuable resource for the company.

Do et al. (2015) who examined the effect of political connections on firm value in the governor election showed that companies with connections to governors could increase firm value to 1.36\%. Wong's research results, 2010; Do et al., 2015; Ang et al., 2013; Wati et al., 2016b; Wati, 2017; Maulana and Wati, 2019 show that political connections have a significant positive effect on firm value. Based on the theory supported by previous research, the first research hypothesis is made:

$\mathrm{H} 1=$ Political connection has a positive effect on firm value. 


\section{The Influence of Family Ownership Structure on Firm Value}

A family company is a company that has dominant shareholders (Claessens et al., 2000). As the primary owner of the company, the family can participate in managing the company and carry out maximum supervision. With full supervision and control, the company will improve its performance (Wati et al., 2019). There is a responsibility by the owner, namely the family, so the decisions taken will be aimed at increasing the value of the company. The majority of ownership of public companies in Indonesia is owned by families (Claesans et al., 2020; Wati et al., 2019). Villalonga and Amit (2006) found that family ownership will add value to the company when the founder becomes CEO or Chairman and CEO of the family company. However, when the descendant of the founder becomes CEO, the company's value will fall.

The role of concentrated ownership in a company is still a puzzle, whether this concentrated ownership has a positive, negative, or no effect on firm value. Some researchers say that concentrated ownership can serve as a corporate governance mechanism to monitor better and effective management so that it will reduce agency conflicts and increase company value, but on the other hand, the presence of concentrated ownership and their involvement in management is thought to be able to control company resources for personal interests (expropriation) and at the expense of the interests of minority shareholders (Shleiver and Vishny, 1986; Tian \& Cheung, 2013; Wati et al., 2019). This is consistent with the Positive Incentive Effect (PIE) and Negative Entrenchment Effect (NEE) arguments put forward by Claessens et al. (2000). The Positive Incentive Effect (PIE) argument states that controlling shareholders will not expropriate minority shareholders because controlling shareholders are the most disadvantaged if there is a decline in the value of the company due to this expropriation. The Negative Entrenchment Effect (NEE) argument states that controlling shareholders use their ability to control management for personal gain by expropriating minority shareholders (Claessens et al., 2000).

The presence of large shareholders (controllers) can have a positive impact on firm value. The benefit shared hypothesis and Positif Incentive Effect show that large shareholders have the power to reduce agency conflicts between management and stakeholders in a company. Concentrated ownership can function as a corporate governance mechanism to monitor better and effective management to reduce agency conflicts (Isik and Soykan, 2013; Martínez \& Requejo, 2017; Wati et al., 2019). Based on the theory supported by previous research, a second hypothesis is made, namely:

$\mathrm{H} 2$ = Family ownership structure has a positive effect on firm value.

\section{The Role of Political Connections in Strengthening the Influence of Family Ownership on Firm Value}

The intense political connections and the controlling role of the family and the state in companies in Indonesia, with weak legal protection and high levels of corruption, make political connections very valuable to companies. Political connections have proven to be able to provide preferential treatment and convenience in various accesses; such as easy access to funding, government procurement contracts, public policies, subsidies and taxes, ease of trade licensing, access to company IPOs (Wati, 2017).

Chen et al. (2011) examined the incentives of family-controlled Chinese listed companies to build their political connections and organizational structures as measured by shareholding structure and board composition. As a result, family firms listed on the capital market are more likely to build political relationships when the market is less developed, and the Government is stronger in controlling resources. Controlling shareholders of family companies with political connections tend to concentrate on their shareholdings and dominate the board of directors so that they can make deals with government officials secretly and enjoy the exclusive benefits between them.

Boubakri et al. (2008) studied 245 privatized companies in 27 developing and 14 developed countries for the period 1980-2002. The results show that political connections in companies are positively related to remaining government ownership and negatively related to foreign ownership. Tian and Cheung (2013) examined political connections, controlling shareholders, and the performance of companies listed on the Shanghai and Shenzen Stock Exchanges. As a result, political connections can increase the value of companies controlled by the family, but political connections do not significantly affect the value of companies controlled by the Government. Political connections are proven to be able to obtain government protection, such as larger bank loans, long-term credit, lower real effective tax rates, and larger government subsidies. Based on the theory supported by previous research, a third hypothesis is made, namely:

H3: Political connections moderate the influence of family controlling shareholders on firm value 


\section{Methodology}

The population in this study were manufacturing companies listed on the IDX for the 2005-2017 period. Determination of the sample using a purposive sampling method, namely determining the sample based on predetermined criteria, namely: publishing financial reports during the study period, and the company has complete data related to the research variables. Based on these criteria, a total sample size of 30 companies was obtained within 13 years, then the number of observations was 390 (panel data).

The political connection variable uses a dummy variable, namely 1 for companies with political connections and 0 for companies not connected with politics. The criteria for political connection in this study follow Faccio (2006) and Wati (2017), where one of the company's largest shareholders (directly or indirectly controlling the company has at least 10\% ownership of shares), or one of the top officials (CEO, Board of Commissioners, President Director, Vice President Director, Secretary) is a member of parliament, minister, head of state, or has an emotional relationship with politicians or political parties.

Family ownership structure uses dummy variables, namely 1 for companies controlled by the family with a level of ownership control (cut off) of $10 \%-50 \%$, and 0 vice versa. The definition of family used in this study is as used by Claessans et al. (2000) and Wati et al. (2019), namely all individuals and companies whose ownership is recorded (ownership of 5\% and above must be recorded), except for public companies, state, financial institutions (such as investment institutions, mutual funds, insurance, pension funds, banks, and cooperatives). The firm value uses the proxy Tobin's Q.

The research model used control variables, namely, profitability and firm age, to control for other independent variables outside the model. Profitability is measured using Return on Assets, and firm age is measured by calculating the number of company ages or years since listing on the capital market to the period of the study by Li et al. (2012) and Cheng (2013), Wati et al. (2019). Table 1 below explains the research variables:

Tabel 1. Research Variables

\begin{tabular}{|c|c|c|}
\hline Variable & Indikator & Sources \\
\hline \multicolumn{3}{|l|}{ Dependent Variable: } \\
\hline Firm Value (Y) & Tobin's $\mathrm{Q}=\frac{M V+T D}{T A}$ & $\begin{array}{l}\text { Do et al., 2013; Ang et al., 2013; Wati et } \\
\text { al., 2016b; Wati, } 2017\end{array}$ \\
\hline Market to Book Value & Market Value/Book Value & \\
\hline \multicolumn{3}{|l|}{ Independent Variable: } \\
\hline Political Connection $\left(X_{1}\right)$ & $\begin{array}{l}\text { Dummy Variable: } \\
1=\text { politically connected } \\
0=\text { not politically connected }\end{array}$ & Faccio, 2006; Wati et al., 2019 \\
\hline Family Ownership $\left(X_{2}\right)$ & $\begin{array}{l}\text { Dummy Variable } \\
1=\text { if there is the family concentration } \\
0=\text { if there is no family concentration }\end{array}$ & Claessens et al., 2000; Wati et al., 2019 \\
\hline
\end{tabular}

Research Model

Information:

$$
\begin{aligned}
& \text { Firm }_{\text {Value }}=\alpha_{1}+\beta 1 P O L_{i t}+\beta 2 \text { Fam }_{i t}+\beta 3 R O A_{i t}+\beta 4 A g e_{i t}+\varepsilon_{1} \ldots(1) \\
& \text { Firm }_{\text {Value }}=\alpha_{1}+\beta 1 P O L_{i t} * \text { Fam }_{i t}+\beta 2 R O A_{i t}+\beta 3 \text { Age }_{i t}+\varepsilon_{2} \ldots \text { (2) }
\end{aligned}
$$

$\propto \quad$ : Constants

Firm Value: Tobin's Q \& Market to Book Value

PoL: politically connected firms

Family: Family ownership structure

ROA: Return on Assets

Age: Firm Age

$\beta$ : Regression coefficient

E: error 


\section{Result}

Table 2 below presents a description of the research variables, namely political connections, family ownership, and firm value. The number of manufacturing companies is as many as 30 sample companies with the observation year from 2005-2017 so that the entire observation years are 390 companies (panel data). The following is an explanation for the variable description:

Table 2. Descriptive Statistics

\begin{tabular}{llllll}
\hline & N & Minimum & Maximum & Mean & Std. Deviation \\
\hline TOBIN'S Q & 390 & 0.2797 & 23.2863 & 2.6565 & 3.0388 \\
MBV & 390 & -1.1452 & 82.4506 & 3.8377 & 8.2250 \\
POL & 390 & 0 & 1.00 & 0.5769 & 0.4947 \\
FAM CUT 10\% & 390 & 0 & 1.00 & 0.9154 & 0.2787 \\
FAM CUT 20\% & 390 & 0 & 1.00 & 0.9154 & 0.2787 \\
FAM CUT 30\% & 390 & 0 & 1.00 & 0.8667 & 0.3404 \\
FAM CUT 40\% & 390 & 0 & 1.00 & 0.8179 & 0.3864 \\
FAM CUT 50\% & 390 & 0 & 1.00 & 0.7744 & 0.4185 \\
ROA & 390 & -0.4910 & 0.4453 & 0.0787 & 0.1363 \\
FIRM AGE & 390 & 1 & 35 & 19 & 5 \\
\hline SOurce: Data Pron
\end{tabular}

Source: Data Processed, 2020

Based on the data in table 2 above, it can be seen that the main value of the company is 0.2797 , the max firm value is 23.2863 , has an average value of 2.6565 , and has an std value deviation of 3.0388. The value of political connection and family ownership uses dummy variables. The average value of political connections is 0.5769 , which is $57.69 \%$ of the sample companies are politically connected. The average value of family ownership is 0.9154 at $10 \%$, and $20 \%$ cut off, meaning that manufacturing companies are concentrated in families at $91.54 \%$ at 10 and $20 \%$ cut-offs. The mean value of family ownership at the cut-off of 30\%, 40\%, and 50\% success was $86.67 \%, 81.79 \%$, and $77.44 \%$, respectively. This empirical evidence shows that ownership in manufacturing companies in Indonesia is concentrated in families.

\section{Research Hypothesis Testing}

Testing the hypothesis in this study using the Common Effect Model method using the General Least Square (weighted cross-section) because the panel data in this study has a smaller amount of time than the number of individuals and contains heteroscedasticity. The following table 3 describes the results of hypothesis testing:

Table 3. Testing Results of Model 1

\begin{tabular}{|c|c|c|c|c|c|c|}
\hline \multicolumn{7}{|c|}{ Firm $_{\text {Value }}=\alpha_{1}+\beta 1 P O L_{i t}+\beta 2$ Fam $_{i t}+\beta 3 R O A_{i t}+\beta 4 A g e_{i t}+\varepsilon_{1} \ldots(1)$} \\
\hline & & & PANEL A & & & \\
\hline \multirow{3}{*}{ Variables } & \multicolumn{5}{|c|}{ Research Model (Tobin's Q) } & \multirow{3}{*}{ Result } \\
\hline & & & Cut Off & & & \\
\hline & $10 \%$ & $20 \%$ & $30 \%$ & $40 \%$ & $\mathbf{5 0 \%}$ & \\
\hline Constant & -0.323763 & -0.323763 & -0.375567 & -1.096745 & -1.132168 & \\
\hline PC & $0.333008 * * *$ & $0.333008 * * *$ & $0.317718 * * *$ & $0.492851 *$ & $0.574137 * *$ & Supported \\
\hline FAMILY & $0.650757 * * *$ & $0.650757 * * *$ & $0.731770 * * *$ & $1.006860 * * *$ & $1.066198 * * *$ & Supported \\
\hline ROA & $9.593641 * * *$ & $9.593641 * * *$ & $9.656399 * * *$ & $11.09764 * * *$ & $11.03665 * * *$ & Supported \\
\hline AGE & $0.044484 * * *$ & $0.044484 * * *$ & $0.044880 * * *$ & $0.094713 * * *$ & $0.094259 * * *$ & Supported \\
\hline R-Squared & 0.405520 & 0.405520 & 0.413976 & 0.349382 & 0.354705 & \\
\hline Adjusted R-squared & 0.399328 & 0.399328 & 0.407872 & 0.342604 & 0.347984 & \\
\hline F-statistic & $65.48580 * * *$ & $65.48580 * * *$ & $67.81580 * * *$ & $51.55194 * * *$ & $52.76925 * * *$ & \\
\hline
\end{tabular}




\begin{tabular}{|c|c|c|c|c|c|c|}
\hline \multirow{3}{*}{ Variables } & \multicolumn{5}{|c|}{ Robust Model (MBV) } & \multirow{3}{*}{ Result } \\
\hline & \multicolumn{5}{|c|}{ Cut Off } & \\
\hline & $10 \%$ & $20 \%$ & $30 \%$ & $40 \%$ & $\mathbf{5 0 \%}$ & \\
\hline Constant & -7.647713 & -7.647713 & -7.495112 & -7.175038 & -7.267471 & \\
\hline $\mathbf{P C}$ & $1.564091 * *$ & $1.564091 * *$ & $1.458272 * *$ & $1.310118^{*}$ & $1.482948 * *$ & Supported \\
\hline FAMILY & $2.388098^{*}$ & $2.388098^{*}$ & $2.404109^{* *}$ & $2.126531^{* *}$ & $2.276875^{* * *}$ & Supported \\
\hline ROA & $27.91355^{* * *}$ & $27.91355^{* * *}$ & $28.07732 * * *$ & $28.17432^{* * * *}$ & $28.05724 * * *$ & Supported \\
\hline AGE & $0.332178^{* * *}$ & $0.332178^{* * *}$ & $0.332093^{* * *}$ & $0.337546^{* * *}$ & $0.336436^{* * *}$ & Supported \\
\hline R-Squared & 0.346032 & 0.346032 & 0.349371 & 0.349443 & 0.352964 & \\
\hline Adjusted R-squared & 0.339202 & 0.339202 & 0.342576 & 0.342649 & 0.346207 & \\
\hline F-statistic & 50.66396 *** & 50.66396 *** & $51.41534^{* * * *}$ & $51.43154 * * *$ & $52.23254 * * *$ & \\
\hline
\end{tabular}

Source: Data processed, 2020

*** $\operatorname{Sig} \alpha 1 \%$, ** Sig $\alpha 5 \%,{ }^{*} \operatorname{Sig} \alpha 10 \%$.

Hypothesis testing is done by comparing t-statistics with t-tables or by looking at the significance value. Based on table 3 above, political connections have a significant positive effect on firm value proxied by Tobin's Q on all ownership boundaries, namely 10\%, 20\%, 30\%, 40\%, and 50\%. Empirical evidence shows that the value of companies that are politically connected is higher than companies that are not politically connected. The results of robust model testing using the dependent variable Market to Book Value show consistent results, where political connections have a significant positive effect on Market to Book Value across all ownership boundaries, namely $10 \%, 20 \%, 30 \%, 40 \%$, and $50 \%$. The results of testing the effect of family ownership on firm value show that there is a positive and significant influence between family ownership on the value of the company proxied by Tobin's Q on all ownership limits, namely 10\%, 20\%, 30\%, 40\%, and 50\%.

These results support the second research hypothesis, where family ownership has a significant positive effect on firm value. The results of robust model testing using the dependent variable Market to Book Value show consistent results, where family ownership has a significant positive effect on Market to Book Value on all ownership limits, namely $10 \%, 20 \%, 30 \%, 40 \%$, and $50 \%$. This empirical evidence shows that there is a concentration of family ownership in manufacturing companies in Indonesia. The concentration on family ownership can increase the value of the company. 
Table 4. Testing Results of Model 2, Moderating Effect

\begin{tabular}{|c|c|c|c|c|c|c|}
\hline \multicolumn{7}{|c|}{ Firm $_{\text {Value }}=\alpha_{1}+\beta 1 P O L_{i t} *$ Fam $_{i t}+\beta 2 R O A_{i t}+\beta 3 A g e_{i t}+\varepsilon_{2} \ldots(2)$} \\
\hline \multirow{4}{*}{ Variables } & \multicolumn{5}{|c|}{ PANEL A } & \multirow{4}{*}{ Result } \\
\hline & \multicolumn{5}{|c|}{ Research Model (Tobin's Q) } & \\
\hline & \multicolumn{5}{|c|}{ Cut Off } & \\
\hline & $10 \%$ & $20 \%$ & $30 \%$ & $40 \%$ & $50 \%$ & \\
\hline Constant & 0.128476 & 0.128476 & 0.059900 & 0.039210 & 0.004531 & \\
\hline PC*FAMILY & $0.483737 * * *$ & $0.483737 * * *$ & $0.557081 * * *$ & $0.537805 * * *$ & $0.610392 * * *$ & Supported \\
\hline ROA & $9.152373 * * *$ & $9.152373 * * *$ & $9.075869 * * *$ & $9.200111 * * *$ & $8.884215^{* * * *}$ & Supported \\
\hline AGE & $0.052052 * * *$ & $0.052052 * * *$ & $0.054831 * * *$ & $0.055875 * * *$ & $0.059241 * * *$ & Supported \\
\hline R-Squared & 0.409692 & 0.409692 & 0.415355 & 0.411858 & 0.409131 & \\
\hline Adjusted R-squared & 0.405092 & 0.405092 & 0.410800 & 0.407275 & 0.404527 & \\
\hline \multirow[t]{2}{*}{ F-statistic } & $89.06712 * * *$ & $89.06712 * * *$ & $91.17323 * * *$ & $89.86806 * * *$ & $88.86077 * * *$ & \\
\hline & \multicolumn{5}{|c|}{ PANEL B } & \\
\hline \multirow{3}{*}{ Variables } & \multicolumn{5}{|c|}{ Robust Model (MBV) } & \multirow{3}{*}{ Result } \\
\hline & \multicolumn{5}{|c|}{ Cut Off } & \\
\hline & $10 \%$ & $20 \%$ & $30 \%$ & $40 \%$ & $50 \%$ & \\
\hline Constant & -1.568775 & -1.568775 & -1.554882 & -1.563816 & -1.529267 & \\
\hline PC*FAMILY & $0.682723 * * *$ & $0.682723 * * *$ & $0.812205^{* * *}$ & $0.863990 * * *$ & $1.023591 * * *$ & Supported \\
\hline ROA & $16.19760 * * *$ & $16.19760 * * *$ & $16.18089 * * *$ & $16.33120 * * *$ & $15.99356 * * *$ & Supported \\
\hline AGE & $0.141632 * * *$ & $0.141632 * * *$ & $0.139349 * * *$ & $0.138546^{* * *}$ & $0.138280 * * *$ & Supported \\
\hline R-Squared & 0.375524 & 0.375524 & 0.375895 & 0.377260 & 0.377029 & \\
\hline Adjusted R-squared & 0.370645 & 0.370645 & 0.371019 & 0.372395 & 0.372162 & \\
\hline F-statistic & $76.97182 * * *$ & $76.97182 * * *$ & $77.09377 * * *$ & $77.54329 * * *$ & $77.46710 * * *$ & \\
\hline
\end{tabular}

Source: Data processed, 2020

$* * * \operatorname{Sig} \alpha 1 \%$, ** Sig $\alpha 5 \%, * \operatorname{Sig} \alpha 10 \%$.

The results of testing the interaction of political connections on the effect of family ownership on the value of manufacturing companies show that there is a positive and significant influence between family ownership on the value of the company proxied by Tobin's $Q$ on all ownership boundaries, namely $10 \%, 20 \%, 30 \%, 40 \%$, and $50 \%$. These results support the third research hypothesis, where political connections strengthen the effect of family ownership on firm value. The results of robust model testing using the dependent variable Market to Book Value show consistent results, where political connections strengthen the influence of family ownership on firm value (Market to Book Value) at all ownership boundaries, namely 10\%, 20\%, 30\%, 40\%, and 50\%.

The control variables return on assets, and firm age has a positive effect on firm value in all $10 \%-50 \%$ cut-offs in all research models. Profitability is a good performance indicator of increasing company value. The high return on assets in manufacturing companies shows that the company is assessed by the market as having a great ability to improve and control company resources. Investors believe that the longer the company exists in the capital market, the more business experience the company has and the company will be aware of the challenges and conditions of the real business world so that every policy made by the company will be more optimal and by itself can increase the firm value.

\section{Discussion}

\section{The Effect of Political Connections on Firm value}

The results of testing the research hypothesis show that political connections have a significant positive effect on firm value, meaning that the more the company is connected to politics, the more firm value increases. The results of this study support the theory of political connections put forward by North (1990) and Olson (1993), where companies with political connections will receive benefits such as contracts or profitable subsidies that have an impact on increasing firm value. The results of this study are also consistent with previous researchers Goldman et al., 2009; Wong, 2010; Do et al., 2012; Ang et al., 2013; Wati et al., 2016b, Wati (2017), and Maulana \& Wati (2019) which show that political connections have a significant positive effect on firm value. 
The results of this study indicate empirical evidence that entrepreneurs believe that political connections can provide preferential treatment and convenience in various accesses as well as provide a sense of security for business actors for the investment they make. Companies that have a relationship with the authorities can get strategic benefits, such as knowing earlier about the regulations made by the Government. Companies can lobby politically for the regulation they want in exchange for donations and votes. Regulations were not created to serve the public interest but to protect monopolistic rent (Purwoto, 2011; Cooper et al., 2010; Do et al., 2013; Wati, 2017).

Bribery is the primary tool and mode for entrepreneurs to change policies that protect people's rights from governance in the oil and gas, infrastructure, and strategic food sectors. Politicians closest to the bureaucrats are the target of lobbying. A large number of corruption cases with the primary mode of bribery committed by the private sector to several politicians, especially from the ruling party, resulted in many state projects falling into the hands of corrupt private companies and in turn alienating the interests of the people at large. This is in line with the handling of corruption where business people show that the number of corruptors has increased significantly from year to year. Companies that should already have a better accountability and transparency system than the bureaucracy are more active in tempting bribes and gratuities to the bureaucracy (Umar, 2016). The strategy undertaken by entrepreneurs to gain a competitive advantage in achieving company goals is no longer only through a generic strategy (low cost, differentiation, and focus) but more importantly building political connections. When conditions of regular competition, Porter's generic strategy is generally carried out by companies, but when the competition is abnormal or unhealthy, companies will use political connections as one of their business strategies (Wati, 2016a).

According to Goldman et al. (2009), companies can even get benefits, especially in terms of reducing competition costs, reducing regulatory obligations, or making it easier to get contracts related to government projects. Companies related to the regime will have their facilities in terms of import permits compared to competitors (Mobarak and Purbasari, 2009).

\section{The Effect of Family Ownership Structure on Firm Value}

Testing the effect of family ownership structure on firm value shows that family ownership structure has a significant positive impact on firm value. The results of this study support the benefit shared hypothesis theory, which shows that large shareholders have the power to reduce agency conflicts between management and stakeholders in a company. The results of this study also support the findings of Claessans et al. (2000), Isik and Soykan (2013), Wati et al. (2019) where family ownership has a positive effect on firm value. Large shareholders in the company are motivated to do better monitoring from the manager. Companies with some of the largest shareholders allow these shareholders to monitor each other or a coalition to monitor each other or a coalition to eliminate personal interests.

Concentrated ownership can function as a corporate governance mechanism to monitor better and effective management to reduce agency conflicts (Konijn et al., 2013) so that the presence of controlling shareholders in the company will have a positive impact on the company value. These results suggest that large shareholders do not necessarily generate personal benefits (selfishness) at the expense of minority shareholders. The results of this study support the Positive Incentive Effect (PIE) argument which states that controlling shareholders will not expropriate minority shareholders because controlling shareholders are the most disadvantaged if there is a decrease in the value of the company due to this expropriation. Expropriation is considered too expensive for the controlling shareholder. The controlling shareholder of the family tries to get involved in the company to maximize the value of the company by not expropriating. Thus, the results of this study also prove that the agency problem in manufacturing companies decreases with the concentration of family ownership.

\section{The Role of Political Connections in Strengthening the Influence of Family Ownership on Firm Value}

The results of the research on the interaction of political connections on the effect of family ownership on firm value show positive results, where political connections strengthen the influence of family ownership on firm value at all $10 \%-50 \%$ boundaries. The results of this study indicate that the value of companies controlled by politically connected families is higher than companies that are not politically connected. This empirical evidence shows that family ownership structures have a role in determining political connections, this is supported by the findings of Tian and Cheung (2013) and Wati et al. (2019) who found that political connections can increase the value of companies controlled by the family. Political connections are proven to be able to obtain government protection, such as larger bank loans, long-term credit, lower real effective tax rates, and larger government subsidies. The ownership structure of the company plays a part in determining the political connections in the group company. Family controlling shareholders in politically connected companies tend to dominate the board of commissioners and fill the board of 
commissioners from government officials and political party officials so that they can make deals with government officials and enjoy exclusive benefits among them (Chen et al., 2011).

This empirical evidence shows that a large amount of family ownership in the company and the political connections that the company builds can increase firm value. The strong political connections in family companies have attracted investors to invest their funds. The results of this study support the phenomenon of several elections that took place in Indonesia, where family-controlled companies that are connected politically and support election winners experienced a significant increase in the post-election market capitalization value both in 2009 and in 2014 (Wati, 2016a). The increase in the share price of these companies indicates that entrepreneurs and company leaders in developing countries such as Indonesia with high levels of corruption, weak bureaucracy, decisive government intervention strongly believe that political connections are a strategy to achieve company goals, so they make efforts. Significant for fostering political connections to achieve corporate growth (Faccio, 2006).

\section{Conclusion}

The test results show that political connections and family ownership have a positive effect on firm value. The political connections built by family firms can increase company value. These results indicate that political connections are still considered beneficial by various parties such as companies, political parties, and the Government. Entrepreneurs believe that political connections can provide preferential treatment and convenience in multiple accesses as well as provide a sense of security for business actors for the investments they make. The ownership structure also still dominates nepotism in Indonesia. The ownership structure has a very beneficial role for families and colleagues and can also monitor and control the company in full. The existence of concentrated ownership can serve as a corporate governance mechanism to monitor better and more effective management, thereby reducing agency conflicts. The interaction of political connections can strengthen the influence of family ownership on firm value. Empirical evidence shows that the value of companies controlled by politically connected families is higher than companies that are not politically connected. This proves the findings of Wati et al. (2019) that the family ownership structure has a role in determining political connections in Indonesia, especially in manufacturing companies. The results of this study support agency theory (Jensen and Meckling, 1976; Shleifer and Vishny, 1997) and political theory (North, 1990 and Olson, 1993).

Based on the results of the research and the findings of the model in this study, there are several suggestions or suggestions, namely: with the influence of political connections and ownership structures that are concentrated by families which are proven to be able to increase firm value, investors should invest in companies connected to politics and companies that are concentrated by the family with majority ownership, because it is proven to increase company value, for management to be careful about the connections that are built between companies and the Government because political connections also provide benefits and can also have a negative impact on the company's image.

\section{Limitations and Further Research}

This study still has shortcomings and limitations; namely, the study only uses a sample of manufacturing companies, further researchers are expected to use a larger sample using samples from various sectors and compare it with other developing countries. For further researchers, add other independent and moderating variables that can affect firm value, and add different control variables or proxies for firm value to test the robust model.

\section{Acknowledgements}

Great thanks to DP2M DIKTI of Ministry of Research and Technology Republic Indonesia with the research grant contract number, i.e. 5/AKM/PNT/2019, because this research was supported by the project, which has received funding from the Directorate of General for Strengthening Research and Development, the Ministry of Research and Technology Republic Indonesia. Great thanks to Sekolah Tinggi Ilmu Ekonomi (STIE) Muhammadiyah Jakarta Indonesia for the support and assistance in this research. 


\section{References}

Ang, J.S., Ding, D.K., and Thong, T.Y., 2013. Political Connection and Firm Value. Asian Development Review, Vol. 30 (2), pp. 131-166. Retrieved from: https://www.think-asia.org/handle/11540/1620

Boubakri, N., Cosset, J. C., \& Saffar, W. (2008). Political connections of newly privatized firms. Journal of corporate finance, 14(5), 654-673. https://doi.org/10.1016/j.jcorpfin.2008.08.003

Chaney, P. K., Faccio, M., \& Parsley, D. (2011). The quality of accounting information in politically connected firms. Journal of Accounting and Economics, 51(1-2), 58-76. https://doi.org/10.1016/j.jacceco.2010.07.003

Chen, C.J., Li, Z., Su, X. and Sun, Z. 2011. Rent-seeking incentives, corporate political connections, and the control structure of private firms: Chinese evidence. Journal of Corporate Finance, 17(2), pp.229-243. https://doi.org/10.1016/j.jcorpfin.2010.09.009

Claessens, S., \& Djankov, S. (1999). Ownership concentration and corporate performance in the Czech Republic. Journal of comparative economics, 27(3), 498-513. https://doi.org/10.1006/jcec.1999.1598

Claessens, S., Djankov, S. and Lang, L.H., 2000. The separation of ownership and control in East Asian corporations. Journal of Financial Economics, 58(1-2), pp.81-112. https://doi.org/10.1016/S0304-405X(00)00067-2

Claessens, S., Djankov, S., Fan, J. P., \& Lang, L. H. (2002). Disentangling the incentive and entrenchment effects of large shareholdings. The journal of finance, 57(6), 2741-2771. https://doi.org/10.1111/1540-6261.00511

Do, Q.A., Lee, Y.T. and Nguyen, B.D., 2015. Political connections and firm value: Evidence from the regression discontinuity design of close gubernatorial elections. Retrieved from https://papers.ssrn.com/id2023191.pdf.

Faccio, M., 2006. Politically connected firms. American Economic Review, 96(1), pp.369-386. https://doi.org/10.1257/000282806776157704

Goldman, Eitan, Jorg Rocholl, dan Jongil So. 2009. Do Politically Connected Boards Affect Firm Value? Review of Financial Studies 22, pp. 2331-2360. https://doi.org/10.1093/rfs/hhn088

Isik, O. and Soykan, M.E., 2013. Large shareholders and firm performance: Evidence from Turkey. European Scientific Journal, ESJ, 9(25). Pp. 23-37. Retrieved from: https://www.researchgate.net/profile/Ozcan_Isik/publication/297439142_Large_Shareholders_And_Firm_Performanc e_Evidence_From_Turkey/links/56df071708ae979addef4db0/Large-Shareholders-And-Firm-Performance-EvidenceFrom-Turkey.pdf

Jensen, M. C., \& Meckling, W. H. (1976). Theory of the firm: Managerial behavior, agency costs and ownership structure. Journal of financial economics, 3(4), 305-360. https://doi.org/10.1016/0304-405X(76)90026-X

Kim, D. W., Kim, B. G., \& Youn, M. K. (2017). Family ownership and firm value: Perspective to related-party transaction and wealth transfer. The Journal of Distribution Science, 15(4), 5-13.

https://doi.org/10.15722/jds.15.4.201704.5

La Porta, R., Lopez-de-Silanes, F., \& Shleifer, A., 1999, Corporate Ownership Around the World, The Journal of Finance, 54(2), 471-517. https://doi.org/10.1111/0022-1082.00115

Lindenberg, E., and Ross, S. 1981. Tobins Q Ratio and Industrial Organization. Journal of Business. 54, pg. 1-32. https://www.jstor.org/stable/2352631

Maulana, A. \& Wati, L. N. (2019). Pengaruh Koneksi Politik Dan Struktur Kepemilikan Manajerial Terhadap Nilai Perusahaan. Jurnal Akuntansi, 8(1), 1-12. DOI: https://doi.org/10.37932/ja.v8i1.59

Martínez, B., \& Requejo, I. (2017). Does the type of family control affect the relationship between ownership structure and firm value?. International Review of Finance, 17(1), 135-146. https://doi.org/10.1111/irfi.12093

Mobarak, A. M., \& Purbasari, D. (2005). Political trade protection in developing countries: Firm level evidence from Indonesia. Available at SSRN 770949. Retrieved from: https://papers.ssrn.com/sol3/papers.cfm?abstract_id=770949

North, D.C. (1990). A transaction cost theory of politics. Journal of theoretical politics, 2(4), 355-367. https://doi.org/10.1177/0951692890002004001

Olson, M. (1993). Dictatorship, Democracy, and Development. The American Political Science Review, 87(3), 567-576. doi:10.2307/2938736. DOI: $10.2307 / 2938736$

Purwoto, L. (2011). Pengaruh koneksi politis, kepemilikan pemerintah. dan keburaman laporan keuangan terhadap kesinkronan dan risiko crash harga saham. Retrieved from: https://repository.ugm.ac.id/94886/

Shleifer, Andrei dan Robert W, Vishny. 1994. Politicians and Firms, Quarterly Journal of Economics, 995-1025. https://doi.org/10.2307/2118354

Tian, L., Cheung, W., 2013. Political Connections, Controlling Shareholders and Post-IPO Performance of China's Listed Companies. Institute of Finance and Development. Nankai University. Retrieved from: https://web.iss.utokyo.ac.jp/kyoten/activities/paper_April24th.pdf

Umar, Haryono. 2016. Corruption the Devil. Penerbit Universitas Trisakti. Jakarta.

Villalonga, B., \& Amit, R. (2006). How do family ownership, control and management affect firm value?. Journal of Financial Economics, 80(2), 385-417. https://doi.org/10.1016/j.jfineco.2004.12.005

Wati, L.N., Sudarsono, R,. and Febrian, E. 2016a. Corporate governance on conglomerates politically connected. International Journal of Business, Economics and Law, 10(1), pp.23-31. http://doi.org/10.9770/jesi.2019.7.1(5) 
Wati, L. N., Primiana, I., \& Sudarsono, R. 2016b. Political connections of conglomerates: Evidence form Indonesia stock exchange. Current Issues in $\quad$ Economics, $\quad$ (12), https://www.researchgate.net/publication/325959859 Political connections of conglomerates Evidence f orm_Indonesia_stock_exchange

Wati, L.N., 2017. Board of Commissioner's Effectiveness on Politically Connected Conglomerates: Evidence from Indonesia. Pertanika journal of social science and humanities, 25, pp.255-270. http://www.pertanika.upm.edu.my/Pertanika\%20PAPERS/JSSH\%20Vol.\%2025\%20(S)\%20Nov.\%202017 /21\%20JSSH(S)-0607-2017-4thProof.pdf

Wati, L.N., Primiana, H.I., Pirzada, K. and Sudarsono, R., 2019. Political connection, blockholder ownership and performance. Entrepreneurship and Sustainability Issues, 7(1), pp.52-68. https://doi.org/10.9770/jesi.2019.7.1(5)

Wati, L. N.; Ramdany, Momon. 2020. Does corporate governance affect the financial reporting quality of politically connected firms? Entrepreneurship and Sustainability Issues, 7(3), 2126-2143. https://doi.org/10.9770/jesi.2020.7.3(45)

Wong, S.H.W., 2010. Political connections and firm performance: The case of Hong Kong. Journal of East Asian Studies, 10(2), pp.275-314. DOI: https://doi.org/10.1017/S1598240800003465

Wu, W., Wu, C., Zhou, C. and Wu, J., 2012. Political connections, tax benefits and firm performance: Evidence from China. Journal of Accounting and Public Policy, 31(3), pp.277-300. https://doi.org/10.1016/j.jaccpubpol.2011.10.005

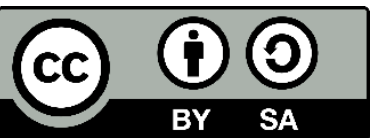

(C) 2021 by the authors. Licensee ACRN Publishing, Austria, Editor in Chief Prof. Dr. Othmar M. Lehner. This article is an open access article distributed under the terms and conditions of the Creative Commons Attribution (CC BY SA) license (https://creativecommons.org/licenses/by-sa/4.0/) 